\title{
PELATIHAN PENGOLAHAN RUMPUT LAUT MENJADI PRODUK SELAI DI KELURAHAN SONGKA KECAMATAN WARA SELATAN KOTA PALOPO
}

\author{
Seaweed Proscessing Training Becomes Jam in Songka Village Wara Selatan \\ Subdistrict, Palopo City
}

\author{
Syahmidarni Al Islamiyah ${ }^{1),}$ Firman Shanty Galung ${ }^{2)}$ \\ 1,Program Studi Teknologi Hasil Pertanian, Politeknik Gorontalo \\ ${ }^{2}$ Program Studi Agribisnis, Universitas Cokroaminoto Palopo \\ Email: syahmi1801@gmail.com ${ }^{1)}$
}

\begin{abstract}
ABSTRAK
Kota Palopo merupakan salah satu daerah di Sulawesi Selatan yang memiliki sumber daya perairan terutama rumput laut. Umumnya, masyarakat masih mengolah dan memasarkan dalam bentuk rumput laut kering dan basah. Salah satu daerah penghasil rumput laut di Kota Palopo adalah Kelurahan Songka Kecamatan Wara Selatan. Hal ini dapat dilihat dari pola mata pencaharian penduduk di Kelurahan Songka yang sebagian besar berprofesi sebagai nelayan budidaya rumput laut. Permasalahan yang dihadapi adalah masih kurangnya pemahaman tentang pengolahan, pengemasan dan teknik penyimpanan yang baik guna memperpanjang masa simpan produk. Oleh karena itu, pengabdian ini sangat tepat dilakukan dalam rangka memberikan pengetahuan dan keterampilan diversifikasi olahan rumput laut. Adapun masyarakat sasaran pengabdian ini adalah ibu rumah tangga dalam hal ini ibu PKK. Tahapan pelaksanaannya terdiri dari identifikasi masalah dan cara pemecahannya, observasi dan sosialisasi, persiapan tim dan teknis pelatihan, penyuluhan dan pelatihan teknik pengolahan, diskusi interaktif, tinjauan dan evaluasi kegiatan. Teknis pelaksanaan kegiatan pengabdian terdiri dari penyuluhan, pelatihan pengolahan selai rumput laut dan diskusi interaktif. Hasil kegiatan pengabdian ini sangat memuaskan. Hal ini terlihat dari sikap penerimaan pihak pemerintah Kelurahan Songka, antusiasme peserta dan ikut terlibat dalam proses pengolahan selama kegiatan. Kekurangan yang dirasakan oleh tim selama pengabdian adalah pemilihan metode penyajian materi yang kurang tepat dengan bahasa materi yang kurang sederhana sehingga peserta kurang mudah memahami. Pengabdian di Kelurahan Songka ini menjadi jembatan terjalinnya kerjasama yang sinergis antara pemerintah, akademisi dan masyarakat dalam meningkatkan sumber daya manusia dan sumber daya alam lokal serta pendapatan rumah tangga di Kota Palopo
\end{abstract}

\section{Kata kunci: pelatihan, rumput laut, selai, Songka}

\section{ABSTRACT}

Palopo City is one of the areas in South Sulawesi that had water resources, especially seaweed. Generally, people still process and market in the form of dry and wet seaweed plants. One of the city's seaweed plant producing areas in Palopo City is Songka Sub-District, South Wara District. Which can see from the pattern of livelihoods of residents in the Songka Village, mostly work as fishermen for seaweed cultivation? The problem faced is still a lack of understanding of processing, packaging, and proper storage techniques to extend the shelf life of the product. Therefore, this dedication is very appropriate to provide knowledge and skills of diversification of processed seaweed. The target community of this service is housewives, in this case, PKK mothers. The implementation phase consists of the identification of problems and how to solve them, observation and socialization, preparation of the team and technical training, counseling, and training in processing techniques, interactive discussion, review, and evaluation of activities. The technical implementation of service activities consists of advice, training in seaweed jam processing, and interactive discussions. The results of this community service were very satisfying. It can see from the attitude of acceptance of the Songka District government, enthusiasm of the participants, and the participants involved in the processing process 
during the activity. The weakness that was felt by the team during the dedication was the selection of the method of presenting the material that was not quite right with the language of the content that was not simple enough so that the participants were not easy to understand. The dedication in Songka Urban Village is a bridge to establish synergic cooperation between the government, academics, and the community in increasing local human and natural resources and household income in Palopo City.

Keywords: training, seaweed, jam, Songka

\section{PENDAHULUAN}

Rumput laut merupakan komoditi unggulan perikanan di Sulawesi Selatan khususnya Kabupaten Luwu dan Kota Palopo. Produksi rumput laut di Kota Palopo pada tahun 2014 mencapai 3.112,31 ton (Waluyo, dkk., 2017). Meningkatnya permintaan pasar baik domestik dan luar negeri mendorong semakin berkembangnya usaha rumput laut. Masyarakat kebanyakan mengolah dan dipasarkan dalam bentuk rumput laut kering dan basah. Hal ini menyebabkan nilai tambah lebih rendah sehingga keuntungan lebih besar diperoleh oleh negara importir. Oleh karena itu, perlu dilakukan peningkatan nilai tambah dengan cara pengolahan dan ataupun diversifikasi produk.

Pengolahan rumput laut menjadi produk olahan yang memiliki nilai tambah dan nilai ekonomi tinggi. Salah satunya dengan mengolah rumput laut menjadi selai. Selai merupakan produk semibasah yang umumnya diolah dari buah-buahan yang dihancurkan dan dimasak sampai berbentuk setengah padat (Margono, et al., 1993)

Rumput laut, dengan kandungan polisakaridanya yang cukup besar merupakan bahan yang potensial sebagai sumber serat pangan (Dwiyitno, 2011), sehingga sangat cocok jika diolah menjadi selai. Proses pengolahannya juga terbilang mudah dengan menggunakan alat yang sederhana. Hal ini menjadi peluang bagi masyarakat terutama ibu rumah tangga untuk dijadikan usaha rumahan.

Pelatihan kepada ibu-ibu Pembinaan Kesejahteraan Keluarga (PKK) di Kelurahan Songka Kecamatan Wara Selatan Kota Palopo merupakan kegiatan yang dilakukan sebagai salah satu upaya mendiversifikasi olahan rumput laut. Selain itu, mengoptimalkan peran akademisi sebagai mitra untuk masyarakat terutama masyarakat Kabupaten Palopo. Hal ini dilatarbelakangi dengan melihat pola mata pencaharian penduduk di Kelurahan Songka sebagian besar berprofesi sebagai nelayan budidaya rumput laut. Kegiatan pelatihan ini diharapkan menghasilkan produk yang dapat dijadikan sebagai usaha dapat meningkatkan pendapatan asli daerah umumnya dan pendapatan rumah tangga khususnya.

\section{METODE PELAKSANAAN KEGIATAN}

Pengabdian ini dilakukan pada buan Januari 2017 di Kelurahan Songka, Kecamatan Wara Selatan, Kota Palopo.

Pelaksanaan program pengabdian ini dilaksanakan dengan beberapa tahap yaitu

1. Identifikasi masalah dan cara pemecahannya

2. Observasi dan sosialisasi kepada pihak pemerintahan setempat ; menjelaskan tujuan dan manfaat kegiatan, menyesuaikan kesediaan pemerintah dan masyarakat sasaran, mengkomunikasikan SOP pelatihan.

3. Persiapan tim dan teknis pelatihan ; kebutuhan, waktu, biaya dan SOP pengabdian

4. Penyuluhan dan pelatihan teknik pengolahan ; pemaparan singkat materi pengabdian, praktek pengolahan selai rumput laut

5. Diskusi Interaktif ; menjalin interaksi dengan peserta, melibatkan peserta dalam pengolahan

6. Tinjauan dan Evaluasi Kegiatan ; hasil yang diperoleh, kepuasan peserta setelah mengikuti peatihan, dan kekurangan selama kegiatan pengabdian untuk perbaikan ke depan.

Metode pelaksanaan pengabdian dilakukan secara langsung dengan memaparkan topik pengabdian menggunakan perangkat audio visual dan praktek (demo masak) pengolahan rumput laut menjadi selai di depan peserta. 
HASIL DAN PEMBAHASAN

Hasil dari beberapa tahapan pelaksanaan pada kegiatan PKM sebagai berikut:

\section{Identifikasi Masalah dan Cara Pemecahannya}

Secara teknis peserta pelatihan mampu mengolah rumput laut untuk lauk/sayur saja. Sebagian besar ibu PKK Kelurahan Songka belum memahami cara mengolah bahan baku yang tepat sampai menjadi produk makanan yang bernilai ekonomi. Selain itu, peserta juga kurang memahami pentingnya pengemasan dan teknik penyimpanan yang baik guna memperpanjang masa simpan produk.

Memberikan pelatihan kepada ibu PKK Kelurahan Songka Kecamatan Wara Selatan Kabupaten Palopo tentang pembuatan selai rumput laut mulai penanganan bahan baku, pengolahan, teknik pengemasan dan penyimpanan yang tepat.

\section{Observasi dan sosialisasi kepada pihak pemerintahan}

Kegiatan observasi dan sosialisasi dilakukan ke lokasi pengabdian dengan tujuan untuk memperoleh informasi berupa gambaran umum masyarakat Kelurahan Songka terkait kegiatan usaha ibu rumah tangga, sumber daya alam yang banyak dimanfaatkan oleh masyarakat, koordinasi dengan pemerintah setempat terkait pengabdian ini.

Hasil observasi dan sosialisasi memberikan informasi bahwa Kelurahan Songka merupakan salah satu daerah di Kota Palopo yang memiliki sumber daya perairan yaitu rumput laut (Burchanuddin, dkk., 2019) yang sebagian besar masyarakatnya menjadikannya sebagai salah satu sumber mata pencaharian. Akan tetapi, menurut keterangan yang diperoleh dari pemerintah setempat, masyarakat terutama ibu rumah tangga memiliki pengetahuan yang kurang mumpuni dalam memanfaatkan rumput laut untuk diolah menjadi produk makanan yang bernilai jual. Oleh karena itu, peru dilakukan suatu upaya dari pemerintah yang bersinergi dengan pihak akademisi untuk memberikan pengetahuan dan keterampilan guna meningkatkan pendapatan masyarakat dari sektor produksi pangan lokal. Oleh karena itu, tim pengabdian berinisiatif untuk melakukan penyuluhan dan pelatihan pengolahan rumput laut bekerjasama dengan ibu PKK di kelurahan ini, yang kemudian ibu PKK sebagai trainer yang nantinya akan membina ibu-ibu rumah tangga yang ada di Kelurahan Songka

\section{Persiapan tim dan teknis pelatihan ; dan Pelaksanaan pengabdian}

Kegiatan persiapan ini dilakukan setelah kegiatan mengetahui masalah dan kondisi masyarakat sasaran. Informasi yang diperoleh kemudian didiskusikan dengan tim pengabdian untuk menyusun rencana mulai mempersiapan kebutuhan, waktu, biaya dan menyusun SOP pelatihan pengolahan rumput laut.

Kebutuhan pelaksanaan pengabdian ini terdiri dari kebutuhan utama dan pendukung. Kebutuhan utama terdiri dari alat dan bahan pengolahan selai rumput laut dan materi penyuluhan. Kebutuhan pendukung seperti perangkat audio visual, absen peserta, konsumsi, dan lain-lain.

Teknis pelaksanaan kegiatan pengadian terdiri dari penyuluhan, pelatihan dan diskusi interaktif. Penyuluhan bertujuan untuk memaparkan materi tentang potendi rumput aut, peluang ekonomi, teknik budidaya dan pengolahan rumput laut, cara memasarkan produk rumput laut. Materi penyuluhan dipaparkan oleh dosen-dosen sesuai bidangnya. Materi disusun dalam bentuk powerpoint dan disampaikan secara langsung dengan media audio visual.

Kegiatan pelatihan dilakukan dengan mempraktekkan cara pengolahan selai rumput laut di depan peserta mulai tahap penanganan bahan baku, persiapan aat dan bahan, proses pengolahan, pengemasan dan teknik penyimpanan. Diskusi Interaktif untuk menjalin interaksi dengan peserta, melibatkan peserta dalam pengolahan. Sesi tanya jawab dilakukan di waktu sembari praktek dan setelah praktek. Dengan demikian, tujuan pelatihan dapat tercapai dan hasilnya terukur dari antusiasme serta pemahaman peserta terhadap materi dan proses pengolahan.

\section{Tinjauan dan Evaluasi Kegiatan}

Tahap ini dapat dilihat setelah semua rangkaian kegiatan pengabdian selesai. Tujuannya untuk melihat sejauh mana tujuan tercapai dan manfaat dapat dirasakan oleh semua pihak yang terlibat terkhusus ibu PKK 
sebagai target utama, serta melihat kekurangan selama proses pengabdian sehingga menjadi perbaikan ke depan.

Hasil kegiatan pengabdian ini sangat memuaskan. Hal ini terlihat dari sikap penerimaan pihak pemerintah Kelurahan Songka yang sangat terbuka dari awal sampai akhir, antusiasme peserta selama kegiatan, menyimak semua materi yang disampaikan, ikut terlibat dalam proses pengolahan dan interaktif. Kegiatan ini berlangsung tanpa hambatan mengingat semua sumber daya telah tersedia, pengetahuan masyarakat tentang gambaran rumput laut sudah ada hanya perlu mengupdate dan memperdalam saja sehingga selama proses penyampaian materi berjalan lancar dan ditutup dengan kegiatan pengolahan yang interaktif.

Kekurangan yang dirasakan oleh tim selama pengabdian adalah pemilihan metode penyajian materi yang kurang tepat atau bahasa materi yang kurang sederhana sehingga peserta kurang mudah memahami oleh peserta. Hal ini karena keragaman usia peserta, profesi yang sebagian besar ibu-ibu rumah tangga dan istri nelayan, dan tingkat pendidikan.

\section{KESIMPULAN}

Kesimpulan pada kegiatan pengabdian ini antara lain :

1. Tercapainya kerjasama yang sinergis antara pemerintah, akademisi dan masyarakat dalam meningkatkan sumber daya manusia dan sumber daya alam lokal.

2. Memperbarui dan meningkatkan pengetahuan dan keterampilan mengolah potensi lokal terutama rumput laut yang ada di desa/kelurahan sehingga terwujud ekonomi mandiri

3. Peningkatan peran serta ibu PKK dalam membantu perekonomian rumah tangga khususnya dan perekonomian daerah umumnya di Kelurahan Songka Kecamatan Wara Selatan Kota Palopo.

\section{DAFTAR PUSTAKA}

Burchanuddin, dkk., 2019. Pola Kemitraan

Petani Rumput Laut di Kabupaten Songka Kecamatan Wara Selatan, Kota Palopo. Prosiding Seminar Nasional Pangan, Teknologi dan Enterpreunership, Makassar.

https://www.researchgate.net/publication/3
32151913_Pola_Kemitraan_Petani_Rump ut_Laut_Di_Kelurahan_Songka_Kecamata n_Wara_Selatan_Kota_Palopo/link/5cd63 376299bf14d9589be74/download Diakses : 1 April 2020.

Dwiyitno, 2011. Rumput Laut sebagai Sumber Serat Pangan Potensial. Jurnal Squalen Vol. 6 Nomor 1. https://www.researchgate.net/profile/Dwiy itno_Dwiyitno/publication/303381338_Se aweed_as_a_potential_source_of_dietary_ fiber/links/573f2b0608ae9ace84133ebe/Se aweed-as-a-potential-source-of-dietaryfiber.pdf. Diakses 41 April 2020.

Margono, T., D. Suryati \& S. Hartinah. 1993. Buku Panduan Teknologi Pangan. Kantor Deputi Menegristek Bidang Pendayagunaan dan Pemasyarakatan Iptek,

Waluyo, dkk., 2017. Rumput Laut Potensi Perairan Kabupaten Luwu dan Kota Palopo, Teluk Bone, Sulawesi Selatan. Plantaxia, Yogyakarta. 